\title{
The urine output definition of acute kidney injury is too liberal
}

Azrina Md Ralib", John W Pickering ${ }^{1 *}$, Geoffrey M Shaw ${ }^{1,2}$ and Zoltán H Endre ${ }^{1,3}$

\begin{abstract}
Introduction: The urine output criterion of $0.5 \mathrm{ml} / \mathrm{kg} / \mathrm{hour}$ for 6 hours for acute kidney injury (AKI) has not been prospectively validated. Urine output criteria for AKI (AKl $\mathrm{V}_{\mathrm{O}}$ ) as predictors of in-hospital mortality or dialysis need were compared.

Methods: All admissions to a general ICU were prospectively screened for 12 months and hourly urine output analysed in collection intervals between 1 and 12 hours. Prediction of the composite of mortality or dialysis by urine output was analysed in increments of $0.1 \mathrm{ml} / \mathrm{kg} / \mathrm{hour}$ from 0.1 to $1 \mathrm{ml} / \mathrm{kg} / \mathrm{hour}$ and the optimal threshold for each collection interval determined. AKI $\mathrm{cr}_{\mathrm{r}}$ was defined as an increase in plasma creatinine $\geq 26.5 \mu \mathrm{mol} / \mathrm{I}$ within 48 hours or $\geq 50 \%$ from baseline.

Results: Of 725 admissions, $72 \%$ had either $\mathrm{AKI}_{\mathrm{cr}}$ or $\mathrm{AK} \mathrm{l}_{\text {vo }}$ or both. AKl $\mathrm{l}_{\mathrm{O}}$ (33.7\%) alone was more frequent than $\mathrm{AKI}_{\mathrm{Cr}}(11.0 \%)$ alone $(P<0.0001)$. A 6-hour urine output collection threshold of $0.3 \mathrm{ml} / \mathrm{kg} / \mathrm{hour}$ was associated with a stepped increase in in-hospital mortality or dialysis (from 10\% above to $30 \%$ less than $0.3 \mathrm{ml} / \mathrm{kg} / \mathrm{hour}$ ). Hazard ratios for in-hospital mortality and 1-year mortality were 2.25 (1.40 to 3.61) and 2.15 (1.47 to 3.15) respectively after adjustment for age, body weight, severity of illness, fluid balance, and vasopressor use. In contrast, after adjustment AKl vo was not associated with in-hospital mortality or 1-year mortality. The optimal urine output threshold was linearly related to duration of urine collection $\left(r^{2}=0.93\right)$.

Conclusions: A 6-hour urine output threshold of $0.3 \mathrm{ml} / \mathrm{kg} /$ hour best associated with mortality and dialysis, and was independently predictive of both hospital mortality and 1-year mortality. This suggests that the current AKI urine output definition is too liberally defined. Shorter urine collection intervals may be used to define AKI using lower urine output thresholds.
\end{abstract}

\section{Introduction}

Urine output is a rapid bedside test for kidney function, and reduced output is the oldest known biomarker for acute kidney injury (AKI); historically described by Galen (200 CE) [1]. A rapid reduction of urine output may be the earliest indication of decreased kidney function. The Risk, Injury Failure, Loss, End stage (RIFLE) consensus definition of the Acute Dialysis Quality Initiative used urine output $<0.5 \mathrm{ml} / \mathrm{kg} / \mathrm{hour}$ for $\geq 6$ hours to define AKI [2]. Subsequent AKI definitions have retained this criterion $[3,4]$.

The urine output criterion (oliguric AKI) consistently classifies more patients as presenting AKI than the creatinine criteria [5-10]. Mortality is higher in those with

\footnotetext{
* Correspondence: john.pickering@otago.ac.nz

'Christchurch Kidney Research Group, Department of Medicine, University of Otago Christchurch, PO Box 4345, Christchurch 8140, New Zealand Full list of author information is available at the end of the article
}

oliguric AKI compared with those without AKI [10]. However, little is known about the comparative mortality for the creatinine criteria verse urine output criteria for AKI. Wlodzimirow and colleagues in a study of 260 patients note that the mortality rate for AKI diagnosed by creatinine alone was greater than for those diagnosed by either creatinine or urine output [8]. Cruz and colleagues noted that AKI defined by urine output was not an independent predictor of mortality [11]. Three studies have investigated the duration of oliguria in relation to creatinine or mortality. Oliguria $(<0.5 \mathrm{ml} /$ $\mathrm{kg}$ /hour) of any duration between 1 and 12 hours was only a fair predictor of subsequent development of AKI according to the RIFLE creatinine criterion [6], and mortality rates increased with increasing duration of oliguria $[9,10]$. To our knowledge, no study has attempted

\section{Biomed Central}


to define an optimum urine output threshold and duration of collection for AKI diagnosis.

We aimed to determine the ideal urine output threshold and collection duration by comparing various thresholds and durations with a predefined composite clinical outcome, namely death or need for dialysis.

\section{Materials and methods}

Data were collected as part of the Fluid Loading in Acute Kidney Injury study, a prospective audit of fluid balance in the ICU of Christchurch Hospital. All patients admitted to the ICU from 1 October 2010 to 31 September 2011 were screened for inclusion. Patients were excluded if they were $<17$ years of age, stayed in the ICU for $<24$ hours, or were without recorded body weight, fluid input or urine output. Follow up was for 12 months. The Upper South A Regional ethics committee of New Zealand (URA/10/EXP/040) approved the study and waived the need for informed consent because only routinely available clinical information was collected.

Hourly fluid input and urine output data were extracted from ICU charts. The most recently documented body weight was used or, if unavailable, the weight reported by the patient or relatives or estimated from the patient demispan was used. Total body water (TBW) was calculated from age and weight according to the formulae [12]:

Male total body water $=20.03-0.1183 \times$ age $($ years $)+0.3626 \times$ weight $(\mathrm{kg})$

Female total body water $=14.46+0.2549 \times$ weight $(\mathrm{kg})$

For each patient, the total urine volume was recorded in moving blocks of duration 1, 2, 3, 4, 5, 7, 8, 9, 10, 11, and 12 hours. Each block began on entry to the ICU and was moved 1 hour at a time until the block ended 24 hours post entry. The minimum urine volume for each collection duration was recorded and divided by the body weight and duration of collection to yield 1-hour to 12-hour urine outputs in millilitres per kilogram per hour. The proportion of patients who died (in-hospital) or needed dialysis was calculated at urine output thresholds of 0.1 to $1 \mathrm{ml} / \mathrm{kg} /$ hour in steps of $0.1 \mathrm{ml} / \mathrm{kg} /$ hour for each collection duration.

Plasma creatinine was collected daily for 7 days and adjusted for cumulative fluid balance at the time of measurement as described by Macedo and colleagues [13]. Baseline creatinine was selected as: the pre-ICU creatinine within 7 to 365 days; or, if unavailable, the last post-discharge creatinine within 90 days; or, if unavailable, the onadmission creatinine. AKI based on plasma creatinine $\left(\mathrm{AKI}_{\mathrm{Cr}}\right)$ was defined as either an increase of $>26.5 \mu \mathrm{mol} / \mathrm{l}$ within 48 hours or $50 \%$ within 7 days of admission [4]. AKI based on 6-hour urine output $\left(\mathrm{AKI}_{\mathrm{UO}}\right)$ was defined as urine output $<0.5 \mathrm{ml} / \mathrm{kg} /$ hour using the lowest 6-hour period of urine output within the first 24 hours [4]. AKI severity stages were separately determined by change in creatinine or urine output according to the Kidney Disease: Improving Global Outcomes definition [4]. Severity of illness was assessed by the Acute Physiological and Chronic Health Evaluation (APACHE) II score [14], and the Simplified Acute Physiological Score II [15].

Results are presented as mean \pm standard deviation for normally distributed variables or median (interquartile range) for non-normally distributed variables. All confidence intervals (CI) are 95\%. For continuous variables, differences in two variables were analysed using an independent $t$ test for normally distributed variables and the Mann-Whitney $U$ test for non-normally distributed variables. For categorical variables, differences in proportions were analysed using the chi-square test.

Determination of whether the numbers of patients classified to each of $\mathrm{AKI}_{\mathrm{Cr}}$ and $\mathrm{AKI}_{\mathrm{UO}}$ were equal was determined by McNemar's test. The predictive performance of urine output for the combined outcome of in-hospital mortality or dialysis was assessed by the area under the curve (AUC) of the receiver operating characteristic (ROC) curve of the sensitivity over one minus specificity. The optimal threshold was defined as the biomarker concentration closest to the point on the ROC curve where sensitivity $=1$ and specificity $=1$.

The ideal urine output threshold for 6-hour collection for prediction of in-hospital mortality or dialysis need was investigated by determining: the ROC optimal threshold; the threshold with identical sensitivity to the creatininebased AKI definition [16]; and the threshold that showed a marked increase in mortality or dialysis after being grouped in increments of $0.10 \mathrm{ml} / \mathrm{kg} /$ hour [17].

A multivariable logistic regression model for prediction of 30-day and 1-year mortality need was built with variables with $P<0.1$ under univariate analysis. Kaplan-Meier and Cox regression survival analyses were used for calculation of hazard ratios for 30-day and 1-year mortality for $\mathrm{AKI}_{\mathrm{UO}}$ and the 6-hour ideal urine output threshold.

The ROC optimal thresholds were determined from the ROC curves for 1-hour to 12-hour urine outputs for mortality or dialysis. A linear regression model was used to fit duration to optimal threshold. The relative risk for mortality or dialysis at each collection duration was calculated for patients with urine outputs below the regression line in comparison with those above the line.

Matlab 2011a (MathWorks, Natick, MA, USA), PRISM 6.0 (GraphPad, La Jolla, CA, USA) and SPSS version 19 (SPSS, Chicago, IL, USA) were used for statistical analyses.

\section{Results}

There were 1,274 ICU admissions, of which 549 were excluded because admission was for $<24$ hours $(n=457)$, 
patients were aged $<17$ years $(n=45)$, there was missing fluid balance data $(n=8)$ or body weight was not recorded $(n=39)$. Of $725 \mathrm{ICU}$ admissions, $522(72 \%)$ had $\mathrm{AKI}\left(\mathrm{AKI}_{\mathrm{Cr}}\right.$ or $\left.\mathrm{AKI}_{\mathrm{UO}}\right)$. The demographic profile and outcomes are shown in Table 1. Those patients with AKI were older, had higher body weight, had greater severity of illness (APACHE II score and Simplified Acute Physiological Score II), and were more likely to be hypotensive or need vasopressors. The mean APACHE II score was $18 \pm 7$, with $40 \%$ of patients $(n=287)$ with a score $>20$. Baseline plasma creatinine was greater in those with AKI, but there was no difference in the distribution of baseline creatinine selection criterion $(P=0.28)$. A higher incidence of AKI was observed in patients with cardiovascular diagnoses, kidney diagnoses or sepsis diagnoses as the primary diagnosis, and in post-surgical patients $(P=$ 0.01 ). Hypertension, ischaemic heart disease, and diabetes mellitus were more common in those with AKI.

\section{Determination of the urine output threshold for 6-hour collection \\ Comparison of $A K I_{C r}$ and $A K I_{U O}$}

One hundred and ninety-eight patients (27.3\%) were diagnosed as both $\mathrm{AKI}_{\mathrm{UO}}$ and $\mathrm{AKI}_{\mathrm{Cr}}$ (Table 2). An additional $33.7 \%(n=242)$ were diagnosed as $\mathrm{AKI}_{\mathrm{UO}}$ only and $11 \%(n=80)$ as $\mathrm{AKI}_{\mathrm{Cr}}$ only $(P<0.0001)$.

One hundred patients died in hospital (13.8\%), and 41 (7.9\%) needed dialysis. Fourteen patients died after dialysis. There were therefore 127 patients with the composite outcome of in-hospital mortality or dialysis. Patients with both $\mathrm{AKI}_{\mathrm{UO}}$ and $\mathrm{AKI}_{\mathrm{Cr}}$ were 3.62 times more likely to die or need dialysis compared with those without AKI (Table 3). Patients with either $\mathrm{AKI}_{\mathrm{UO}}$ or $\mathrm{AKI}_{\mathrm{Cr}}$ were respectively 1.36 or 1.34 times more likely to die or need dialysis compared with those without AKI.

\section{Ideal 6-hour urine output thresholds to predict mortality or dialysis}

The median 6-hour urine output was $0.42(0.27$ to 0.64) $\mathrm{ml} / \mathrm{kg} /$ hour (minimum 0, maximum $4.05 \mathrm{ml} / \mathrm{kg} /$ hour). For a 6-hour collection interval, the AUC for prediction of mortality or dialysis was 0.70 (0.65 to 0.74$)$, with an ROC optimal threshold of $0.31 \mathrm{ml} / \mathrm{kg} /$ hour.

The sensitivity of $\mathrm{AKI}_{\mathrm{Cr}}$ for prediction of mortality or dialysis was $61 \%$ (Table 4). The comparative threshold was defined as the 6-hour urine output that had the same sensitivity as $\mathrm{AKI}_{\mathrm{Cr}}$ for the same outcome. This value was also $0.31 \mathrm{ml} / \mathrm{kg} /$ hour. The specificity of urine output at this threshold (77\%) was greater than for $\mathrm{AKI}_{\mathrm{Cr}}(66 \%)$.

The distribution of patients in each of 11 intervals from $<0.10$ to $>1.00 \mathrm{ml} / \mathrm{kg} /$ hour is shown in Figure $1 \mathrm{~A}$. There was a marked increase in mortality or dialysis need below $0.30 \mathrm{ml} / \mathrm{kg} /$ hour (Figure 1B). Above this threshold $10 \%$ (95\% CI: 7 to $12 \%$ ) died or needed dialysis compared with $36 \%$ (30 to 43\%) below this threshold $(P<0.0001)$. Of the 45 patients with urine output $<0.1 \mathrm{ml} / \mathrm{kg} /$ hour, 29 (64\%) died or needed dialysis.

\section{Urine output $<0.3 \mathrm{mg} / \mathrm{kg} / \mathrm{hour}$}

Because each of the three methods for determining the 6-hour urine output threshold resulted in a threshold of approximately $<0.3 \mathrm{mg} / \mathrm{kg} /$ hour $\left(\mathrm{UO}_{<0.3}\right)$, we assessed its utility in comparison with $\mathrm{AKI}_{\mathrm{UO}}$ and $\mathrm{AKI}_{\mathrm{Cr}}$.

Seventy-six $(36 \%) \mathrm{UO}_{<0.3}$ patients died or needed dialysis, compared with $51(10 \%)$ for $\mathrm{UO}_{\geq 0.3}(P<0.0001)$. The sensitivity of $\mathrm{UO}_{<0.3}$ for prediction of mortality or dialysis was $61 \%$ (52 to $69 \%$ ), specificity was $77 \%$ (73 to $80 \%$ ), positive predictive value was $34 \%$ (29 to $41 \%$ ), and negative predictive value was $90 \%$ (87 to $93 \%$ ). Following adjustment for age, weight, APACHE II score, vasopressor use, fluid balance, presence of $\mathrm{AKI}_{\mathrm{Cr}}$ or dialysis, and baseline creatinine concentration (Table 5), the odds ratio for $\mathrm{UO}_{<0.3}$ was 3.31 (1.97 to 5.57) and that for $\mathrm{AKI}_{\mathrm{UO}}$ was 1.98 (1.14 to 3.43 ).

As shown in Table 6, patients with both $\mathrm{UO}_{<0.3}$ and $\mathrm{AKI}_{\mathrm{Cr}}$ were 5.96 (5.05 to 6.92) times more likely to die or need dialysis compared with those with $\mathrm{UO}_{\geq 0.3}$ and

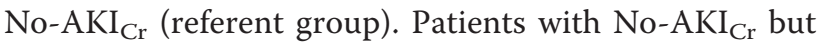
with $\mathrm{UO}_{<0.3}$ were 3.29 (2.77 to 3.63) times and patients with $\mathrm{AKI}_{\mathrm{Cr}}$ and $\mathrm{UO}_{\geq 0.3}$ were 1.96 (1.76 to 2.05) times more likely to die or need dialysis, than those with $\mathrm{UO}_{\geq 0.3}$ and $\mathrm{No}-\mathrm{AKI}_{\mathrm{Cr}}$. The sensitivity of combining $\mathrm{AKI}_{\mathrm{Cr}}$ with $\mathrm{UO}_{<0.3}$ for death or dialysis was $79 \%$ and specificity was $55 \%$, compared with combining $\mathrm{AKI}_{\mathrm{Cr}}$ with $\mathrm{AKI}_{\mathrm{UO}}$ where sensitivity was $85 \%$ and specificity was $31 \%$.

Survival analysis (mortality only) comparing $\mathrm{UO}_{<0.3}$ with $\mathrm{UO}_{\geq 0.3}$ showed greater in-hospital mortality and 1 -year mortality for $\mathrm{UO}_{<0.3}(P<0.0001$; Figure 2$)$. Similarly, $\mathrm{AKI}_{\mathrm{UO}}$ patients had greater in-hospital mortality $(P=0.0044)$ and 1 -year mortality $(P=0.0027)$ than non-AKI $\mathrm{I}_{\mathrm{UO}}$ patients (Figure 2). A survival analysis between three groups - urine output $<0.3 \mathrm{ml} / \mathrm{kg} /$ hour $\left(\mathrm{UO}_{<0.3}\right), 0.3 \leq$ urine output $<0.5 \mathrm{ml} / \mathrm{kg} /$ hour, and urine output $\geq 0.5 \mathrm{ml} / \mathrm{kg} /$ hour (that is, not $\mathrm{AKI}_{\mathrm{UO}}$ ) - showed no difference between $0.3 \leq$ urine output $<0.5 \mathrm{ml} / \mathrm{kg} /$ hour and urine output $\geq 0.5 \mathrm{ml} / \mathrm{kg} /$ hour $(P=0.77$; Figure 2$). \mathrm{UO}_{<0.3}$ patients were more than twice as likely to die in-hospital (hazard ratio: 2.25 (1.39 to 3.64$)$ ) or within 1 year $(2.09$ (1.42 to 3.08$)$ ) than $\mathrm{UO}_{\geq 0.3}$ patients after adjusting for covariates (age, weight, APACHE II score, vasopressor use, fluid balance, presence of $\mathrm{AKI}_{\mathrm{Cr}}$ or dialysis, and baseline creatinine). However, $\mathrm{AKI}_{\mathrm{UO}}$ patients were no more likely to die in-hospital (hazard ratio: 1.48 (0.89 to 2.45$)$ ) or within 1 year (1.43 (0.96 to 2.13)) than non- $\mathrm{AKI}_{\mathrm{UO}}$ patients. 
Table 1 Demographic profile, clinical characteristic and clinical outcome

\begin{tabular}{|c|c|c|c|c|}
\hline Variable & Cohort $(n=725)$ & No AKI $(n=203)$ & AKI $(n=522)$ & $P$ value \\
\hline Age (years) & $59 \pm 18$ & $53 \pm 17$ & $62 \pm 17$ & $<0.0001$ \\
\hline Gender (male) & $455(62.7)$ & $121(59.6)$ & $334(63.9)$ & 0.27 \\
\hline Weight (kg) & $79 \pm 19$ & $74 \pm 18$ & $80 \pm 19$ & $<0.0001$ \\
\hline Height (cm) & $170 \pm 10$ & $170 \pm 10$ & $170 \pm 11$ & 0.87 \\
\hline APACHE \| score & $18 \pm 7$ & $16 \pm 6$ & $19 \pm 7$ & $<0.0001$ \\
\hline SAPS \| & $40 \pm 16$ & $33 \pm 14$ & $43 \pm 16$ & $<0.0001$ \\
\hline Vasopressor usage & $366(50.5)$ & $84(41.4)$ & $282(54.0)$ & 0.002 \\
\hline Hypotension (MAP <60 mmHg) & $384(53.0)$ & $97(47.8)$ & $287(55.0)$ & 0.08 \\
\hline Diuretic usage & $28(3.9)$ & $5(2.5)$ & $23(4.4)$ & 0.22 \\
\hline Baseline plasma creatinine $(\mu \mathrm{mol} / \mathrm{l})$ & $84(71$ to 102$)$ & 78 (69 to 89 ) & 88 (72 to 107$)$ & $<0.0001$ \\
\hline Baseline creatinine selection criterion & & & & 0.28 \\
\hline Pre-ICU 7 days to 1 year & $466(64.3)$ & $122(60.1)$ & $344(65.9)$ & \\
\hline Final 90-day follow up & $195(26.9)$ & $59(29.1)$ & $136(26.1)$ & \\
\hline First ICU admission & $64(8.8)$ & $22(10.8)$ & $42(8.0)$ & \\
\hline Primary diagnosis class & & & & 0.01 \\
\hline Cardiovascular & $70(9.7)$ & $12(5.9)$ & $58(11.1)$ & \\
\hline Endocrine/metabolic & $11(1.5)$ & $0(0)$ & $11(2.1)$ & \\
\hline Gastrointestinal/hepatobiliary/pancreas & $20(2.8)$ & $7(3.4)$ & $13(2.5)$ & \\
\hline Haematology/oncology/immunology & $2(0.3)$ & $1(0.5)$ & $1(0.2)$ & \\
\hline Infective & $3(0.4)$ & $2(1.0)$ & $1(0.2)$ & \\
\hline Renal & $11(1.5)$ & $2(1.0)$ & $9(1.7)$ & \\
\hline Neurological & $67(9.2)$ & $22(10.8)$ & $45(8.6)$ & \\
\hline Respiratory & $145(20.0)$ & $48(23.6)$ & 97 (18.6) & \\
\hline Trauma & $64(8.8)$ & $24(11.8)$ & $40(7.7)$ & \\
\hline Postoperative surgical & $259(35.7)$ & $61(30.0)$ & $198(37.9)$ & \\
\hline Cardiac surgery & $152(20.9)$ & $30(14.8)$ & $122(23.4)$ & \\
\hline Other surgery & $107(14.8)$ & $31(15.3)$ & $76(14.6)$ & \\
\hline Sepsis or septic shock & $44(6.1)$ & $11(5.4)$ & $33(6.3)$ & \\
\hline Miscellaneous & $29(4.0)$ & $13(6.4)$ & $16(3.1)$ & \\
\hline \multicolumn{5}{|l|}{ Baseline co-morbidities } \\
\hline Hypertension & $191(26.3)$ & $40(19.7)$ & $151(28.9)$ & 0.01 \\
\hline Cardiac failure & $16(2.2)$ & $3(1.5)$ & $13(2.5)$ & 0.45 \\
\hline Ischemic heart disease & $133(18.3)$ & $26(12.8)$ & $107(20.5)$ & 0.02 \\
\hline Chronic obstructive airways disease & $54(7.4)$ & $12(5.9)$ & $42(8.0)$ & 0.33 \\
\hline Asthma & $59(8.1)$ & $23(11.3)$ & $36(6.9)$ & 0.05 \\
\hline Diabetes mellitus & $106(14.6)$ & $16(7.9)$ & $90(17.2)$ & 0.001 \\
\hline Kidney disease & $56(7.7)$ & $11(5.4)$ & $45(8.6)$ & 0.15 \\
\hline Malignancy & $62(8.6)$ & $15(7.4)$ & $47(9.0)$ & 0.49 \\
\hline Connective tissue/inflammatory disease & $142(19.6)$ & $45(22.2)$ & $97(18.6)$ & 0.28 \\
\hline Dialysis in the ICU & $41(5.7)$ & $0(0)$ & $41(7.9)$ & $<0.0001$ \\
\hline Hospital mortality & $100(13.8)$ & $19(9.4)$ & $81(15.5)$ & 0.03 \\
\hline Mortality at 1 year & $151(20.8)$ & $30(14.8)$ & $121(23.2)$ & 0.01 \\
\hline Mechanical ventilation & $562(77.5)$ & $159(78.3)$ & $449(86.0)$ & 0.01 \\
\hline Length of MV (hours) & 23 (5 to 83 ) & 18 (5 to 53$)$ & 25 (5 to 92$)$ & 0.02 \\
\hline Length of ICU stay (hours) & 31 (21 to 72 ) & 45 (31 to 95) & $62(39$ to 148$)$ & 0.001 \\
\hline Length of hospital stay (days) & 11 (6 to 20$)$ & 12 (6 to 22$)$ & $14(8$ to 25$)$ & 0.007 \\
\hline
\end{tabular}

Data expressed as mean \pm standard deviation, $n(\%)$, or median (lower quartile to upper quartile). AKI, acute kidney injury (by the creatinine definition or the urine output definition); APACHE, Acute Physiological and Chronic Health Evaluation II Score; MAP, mean arterial pressure; SAPS, Simplified Acute Physiology Score. 
Table 2 Cross tabulation of $\mathrm{AKI}_{\mathrm{U} o}$ and $\mathrm{AKI}_{\mathrm{Cr}}$

\begin{tabular}{|c|c|c|c|}
\hline \multirow[b]{2}{*}{$\mathrm{AKI}_{\mathrm{UO}}$} & \multicolumn{3}{|l|}{$\mathrm{AKI}_{\mathrm{Cr}}$} \\
\hline & No-AKI $\mathrm{Cr}$ & $\mathrm{AKI}_{\mathrm{Cr}}$ & Totals \\
\hline$\overline{\text { No-AKl }}$ & $203(28.0)$ & $80(11.0)$ & 283 (39) \\
\hline$A K l_{\cup O}$ & $244(33.7)$ & $198(27.3)$ & $442(61)$ \\
\hline Totals & $447(62)$ & $278(38)$ & $725(100)$ \\
\hline
\end{tabular}

Data expressed as $n$ (\%). McNemar $P<0.0001$. AKI $\mathrm{Cr}_{\mathrm{r}}$, acute kidney injury by the creatinine definition; $\mathrm{AKI}_{\mathrm{UO}}$, acute kidney injury by the urine output definition.

\section{Duration of urine output}

For each incremental collection period between 1 and 12 hours we calculated the AUC for prediction of mortality or dialysis and compared it with the AUC for the 6-hour interval (Table 7). The optimal threshold for each collection interval was determined from the ROC curves and the relative risk of mortality or dialysis for those below the threshold compared with those above was calculated. The AUC of urine output assessed over periods of 3 to 5 hours and 7 to 12 hours were not different from the 6 -hour period $(P>0.1$; Table 7$)$. The ROC optimal threshold for predicting mortality or dialysis was linearly correlated with duration of urine output $\left(r^{2}=0.93\right.$; Figure 3$)$. The regression line for the optimal threshold was calculated as follows:

Optimal threshold $(\mathrm{ml} / \mathrm{mg} /$ hour$)=0.03 \times$ duration of urine collection (hours) +0.11

Patients with urine output below the regression line were at greater risk of dying or needing dialysis, whereas those patients above the regression line were at lower risk. The relative risk of dying or needing dialysis below the line for a 6-hour urine output was 3.68 (2.68 to 5.04) (Table 7).

\section{Discussion}

In this prospective study, a 6-hour urine output threshold of $0.3 \mathrm{ml} / \mathrm{kg} /$ hour was most clearly associated with the composite clinically important outcomes of mortality or dialysis, while urine output $<0.5 \mathrm{ml} / \mathrm{kg} /$ hour was not associated with in-hospital mortality after adjustment for covariates. A urine output $<0.3 \mathrm{ml} / \mathrm{kg} /$ hour predicted in-hospital mortality and 1-year mortality after adjusting for age, body weight, severity of illness, fluid balance, and vasopressor use. A 6-hour urine output between 0.3 and $0.5 \mathrm{ml} / \mathrm{kg} /$ hour was not associated with increased mortality compared with urine output $>0.5 \mathrm{ml} / \mathrm{kg} /$ hour

AKI was first defined by consensus in 2003 [2]. Alongside a change in the glomerular filtration rate (GFR) criterion that could be measured by its surrogate, a change in plasma creatinine concentration $[2,18]$, AKI could be defined by a decrease in urine output to $<0.5 \mathrm{ml} / \mathrm{kg} /$ hour for 6 hours. The duration and urine output volume were defined by consensus not by physiology. The urine output criterion was incorporated without alteration in subsequent AKI definitions [3,4].

Urine output has three advantages over plasma creatinine. Firstly, low urine output is categorically defined and is not reliant on knowing a baseline urine output, in contrast to plasma creatinine definitions that depend on a baseline creatinine, which is often unknown and therefore must be estimated, a process that introduces significant errors [19-21]. Secondly, a reduced urine output is potentially the first indication of kidney dysfunction especially in critical care settings where hourly urine outputs are routinely measured. Thirdly, recent evidence suggests that in some circumstances creatinine production is dramatically reduced, rendering its use inaccurate as a surrogate for GFR [22]. Urine output changes were shown to precede changes in plasma creatinine and to follow closely the pattern of GFR changes [23]. However, the urine output criterion has not been well validated compared with that of the plasma creatinine criterion. The method of assessing oliguria was not specified. The guideline did not specify whether the reduction in urine output should be defined by the average flow over 6 hours, or from a persistent reduction over the 6 consecutive hours [4]. Using the plasma creatinine Acute Kidney Injury Network definition as the reference standard, Macedo and colleagues compared three different methods of urine output assessment: persistent reduction every hour, average reduction over a moving 6-hourly interval, and a 6-hour interval matching the nursing shift in 317 critically ill patients [9]. Averaging urine output over 6 hours was more sensitive than six successive hourly urine output measurements. We used averaging in this analysis.

At a threshold of $0.5 \mathrm{ml} / \mathrm{kg} /$ hour there was a higher incidence of AKI utilising the urine output definition

Table 3 Mortality or dialysis in $\mathrm{AKI}_{\mathrm{Uo}}$ and $\mathbf{A K I _ { \mathrm { Cr } }}$

\begin{tabular}{|c|c|c|c|c|c|}
\hline & \multicolumn{3}{|c|}{ Mortality or dialysis, $n(\%)^{a}$} & \multicolumn{2}{|c|}{ Relative risk $^{b}(95 \% \mathrm{CI})$} \\
\hline & No-AKI $\mathrm{Cr}$ & $\mathrm{AKI}_{\mathrm{Cr}}$ & Totals & No-AKI $\mathrm{Cr}$ & $\mathrm{AKI}_{\mathrm{Cr}}$ \\
\hline No-AKI $I_{O}$ & $19(9.4)$ & $10(12.5)$ & 29 & 1 (referent) & $1.34(1.20$ to 1.39$)$ \\
\hline$A K l_{\cup O}$ & $31(12.8)$ & $67(33.5)$ & 98 & $1.36(1.20$ to 1.40$)$ & $3.62(3.21$ to 3.94$)$ \\
\hline Totals & 50 & 77 & 127 & & \\
\hline
\end{tabular}

${ }^{a}$ Number (percentage) of mortality or dialysis in each group. ${ }^{b}$ Relative risk of mortality or dialysis to the referent group of No-AKI ${ }_{\mathrm{UO}}$ and No-AKI $\mathrm{Cr}_{\mathrm{r}}$. AKI $\mathrm{Cr}_{\text {, }}$ acute kidney injury by the creatinine definition; $\mathrm{AKI}_{\mathrm{UO}}$, acute kidney injury by the urine output definition; $\mathrm{Cl}$, confidence interval. 
Table 4 Prediction of mortality or dialysis

\begin{tabular}{|c|c|c|c|c|}
\hline & Dialysis-free survival & Mortality or dialysis & Total & \\
\hline \multicolumn{5}{|l|}{$A K I_{C r}$} \\
\hline No-AKI $\mathrm{Cr}_{\mathrm{r}}$ & 397 & 50 & 447 & $N P V=89 \%$ \\
\hline $\mathrm{AKI}_{\mathrm{Cr}}$ & 201 & 77 & 278 & $P P V=28 \%$ \\
\hline \multirow[t]{2}{*}{ Total } & 598 & 127 & 725 & \\
\hline & $S p=66 \%$ & $S n=61 \%$ & & \\
\hline \multicolumn{5}{|l|}{ Urine output } \\
\hline$\geq 0.31 \mathrm{ml} / \mathrm{kg} /$ hour & 462 & 50 & 512 & $\mathrm{NPV}=90 \%$ \\
\hline$<0.31 \mathrm{ml} / \mathrm{kg} / \mathrm{hour}$ & 136 & 77 & 213 & $P P V=34 \%$ \\
\hline \multirow[t]{2}{*}{ Total } & 598 & 127 & 725 & \\
\hline & $S p=77 \%$ & $S n=61 \%$ & & \\
\hline
\end{tabular}

$\mathrm{AKI}_{\mathrm{Cr}}$ acute kidney injury by the creatinine definition; NPV, negative predictive value; PPV, positive predictive value; Sn, sensitivity; Sp, specificity.

compared with the plasma creatinine-based definition (61\% vs. $38 \%)$. Thirty-four per cent of patients with AKI based on urine output were not diagnosed AKI by the plasma creatinine changes. Previous studies have also reported a higher incidence of AKI by urine output compared with the creatinine criteria [5-10]. Eleven per cent $(n=80)$ of our patients had AKI based on creatinine, but not urine output, and they may be described as nonoliguric AKI [10]. These patients may also be those with recovering AKI in that creatinine had yet to fall to baseline although GFR had already recovered [24].

A urine output below an average of $0.3 \mathrm{ml} / \mathrm{kg} /$ hour over 6 hours was associated with higher mortality and dialysis need than $0.5 \mathrm{mg} / \mathrm{kg} /$ hour over 6 hours. Both the ROC optimal threshold for prediction of mortality or dialysis and the threshold that had the same sensitivity as $\mathrm{AKI}_{\mathrm{Cr}}$ for predicting mortality or dialysis were, serendipitously, $0.3 \mathrm{ml} / \mathrm{kg} /$ hour over 6 hours. Interestingly, acute oliguria is classically defined as urine output $<400 \mathrm{ml} /$ day, which is equal to $0.24 \mathrm{ml} / \mathrm{kg} /$ hour in a $70 \mathrm{~kg}$ human $[25,26]$. This is the minimum urine required to eliminate $300 \mathrm{mOsm} /$ day in a maximum urine concentration of $1,200 \mathrm{mOsm} / \mathrm{kg}$. Defining AKI as daily urine output $<500 \mathrm{ml}$ or creatinine $>3.5 \mathrm{mg} / \mathrm{dl}$, Teixerira and colleagues showed that the mean 24-hour urine volume was lower in those who died compared with survivors [27].

Urine output is influenced by many factors including fluid balance, presence of hypotension, and the use of diuretics or vasopressors. These factors were included in the analysis of prediction of hospital mortality and 1-year mortality. After adjusting for these covariates, urine output $<0.3 \mathrm{ml} / \mathrm{kg} /$ hour, but not $<0.5 \mathrm{mg} / \mathrm{kg} / \mathrm{hour}$, was predictive of hospital mortality and 1-year mortality. These patients were approximately twice as likely to die compared with those with urine output $>0.3 \mathrm{ml} / \mathrm{kg} /$ hour.

If a 6-hour urine output threshold of $0.3 \mathrm{ml} / \mathrm{kg} /$ hour was to be used to define AKI rather than $0.5 \mathrm{ml} / \mathrm{kg} / \mathrm{hour}$, then the overall AKI incidence (defined by urine output or $A K I_{c r}$ ) will fall. In this study it would have decreased from
$72 \%(522 / 725)$ to $51 \%(370 / 725)$. Of the 370 patients, 92 would have been diagnosed AKI by the modified urine output criterion alone. These have a meaningful increase in mortality or dialysis risk (Table 6) and should not be overlooked. A less liberal urine output criterion necessarily decreased the sensitivity of the combined urine output and creatinine AKI definition for death or dialysis by $6 \%$, which was compensated by an increase in specificity of $24 \%$.

For clinical applicability and earlier detection of AKI, it may be feasible to assess urine output over $<6$ hours. Reduction of urine output over 2 consecutive hours has been suggested [28]. Prowle and colleagues investigated different durations of consecutive hours of oliguria from 1 to 12 hours in a multicenter study involving 239 patients. Urine output of 4 hours or more best discriminated between $\mathrm{AKI}_{\mathrm{Cr}}$ and No-AKI $\mathrm{Cr}$ [6]. Recently Mandelbaum and colleagues retrospectively interrogated a database of over 25,000 ICU patients and observed an association between urine output thresholds and duration with mortality, and with renal replacement therapy [29]. Urine outputs $>0.3 \mathrm{ml} / \mathrm{kg} / \mathrm{hour}$ resulted in little or no increase in mortality until durations exceeded the 12 hours we assessed in this study. Even less sensitivity of urine output was found for renal replacement therapy. We found a linear relationship between the ROC optimal threshold and duration of urine output for discriminating between mortality or dialysis need and dialysis free-survival from to $0.14 \mathrm{ml} / \mathrm{kg} / \mathrm{hour}$ for 1 hour to $0.47 \mathrm{ml} / \mathrm{kg} /$ hour for 12 hours. There was no difference in relative risk for this outcome as a function of duration from 3 to 9 hours. Although a shorter duration of urine output assessment may provide earlier diagnosis, this may be more susceptible to extraneous factors. A longer period of assessment $>9$ hours is less sensitive and may miss acute changes.

Urine output provides rapid assessment of kidney function, and is often used to guide fluid resuscitation in the critical care setting. A higher target of urine 

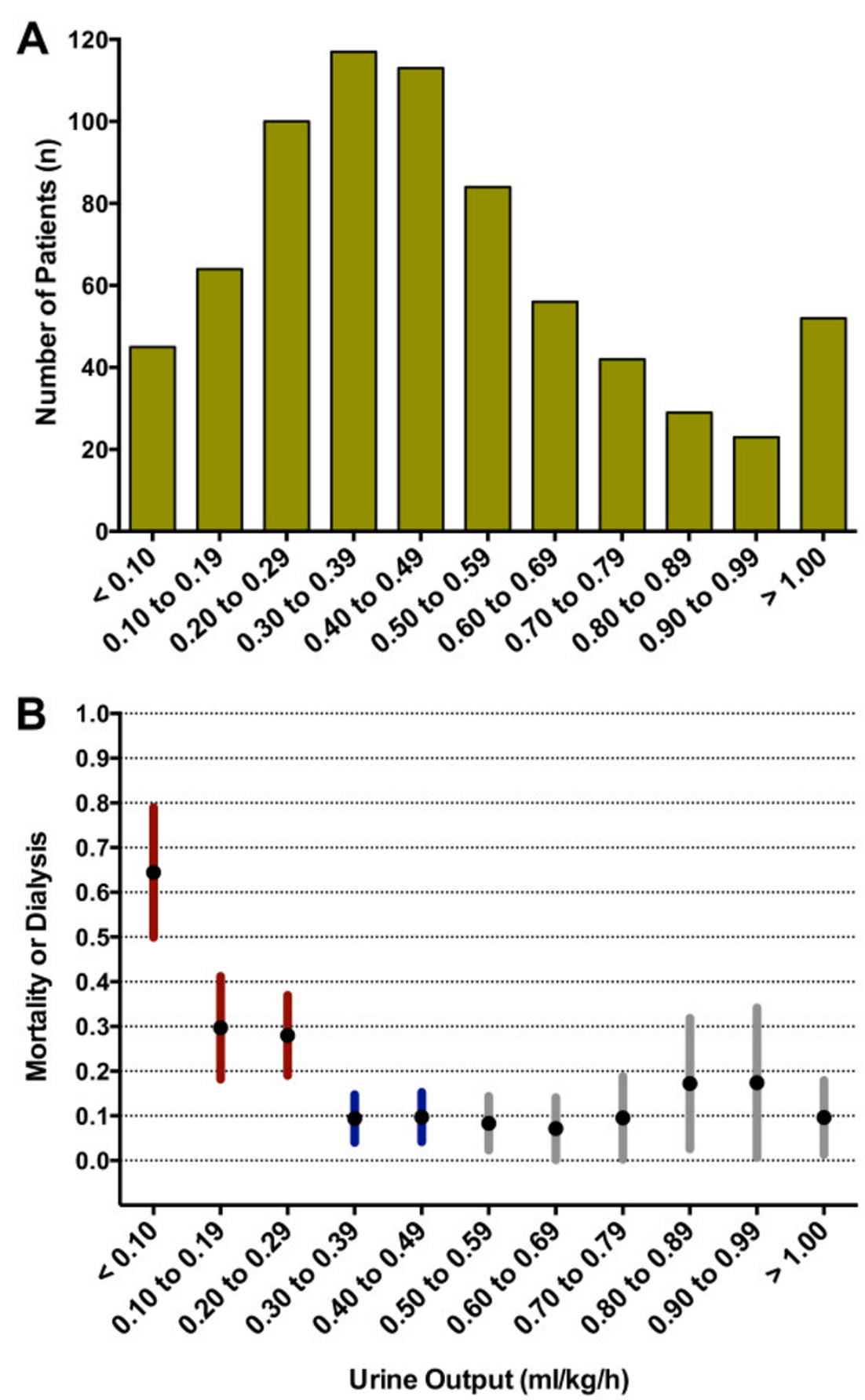

Figure 1 Mortality or dialysis according to 6-hour urine output groups. (A) Number in each group. (B) Proportion of mortality or dialysis in each group. Error bars represent $95 \%$ confidence intervals.

output tends to lead to a higher fluid balance, especially in the setting of nonvolume responsive kidney function. Because there is increasing evidence of a detrimental effect of cumulative fluid balance [30-32], a lower minimum urine output target may reduce fluid accumulation and its associated adverse outcomes. This is akin to permissive hypercapnia in ventilator-induced lung injury, where understanding the adverse effect of high tidal volume ventilation has resulted in a shift in clinical paradigm to accept a higher level of hypercapnia [33]. Similarly, a shift amongst clinicians to accept a lower limit of urine output may reduce the adverse effects associated with fluid accumulation. Nevertheless, the occurrence of oliguria should not be considered in 
Table 5 Univariate analysis for prediction of mortality or dialysis

\begin{tabular}{|c|c|c|}
\hline Variable & $\begin{array}{l}\text { Odds ratio } \\
(95 \% \mathrm{Cl})\end{array}$ & $P$ value \\
\hline Age (years) & $1.02(1.01$ to 1.03$)$ & 0.001 \\
\hline Body weight (kg) & 0.98 (0.97 to 0.99$)$ & 0.005 \\
\hline APACHE II score & 1.18 (1.14 to 1.22$)$ & $<0.0001$ \\
\hline SAPS ॥ & $1.08(1.07$ to 1.10$)$ & $<0.0001$ \\
\hline$A K l_{C r}$ (yes or no) & $3.00(2.02$ to 4.44$)$ & $<0.0001$ \\
\hline Vasopressor use (yes or no) & 1.65 (1.11 to 2.43$)$ & 0.01 \\
\hline $\begin{array}{l}\text { Hypotension, MAP }<60 \text { mmHg } \\
\text { (yes or no) }\end{array}$ & $1.25(0.85$ to 1.84$)$ & 0.26 \\
\hline Diuretic use (yes or no) & $1.60(0.67$ to 3.86$)$ & 0.29 \\
\hline Fluid balance (percentage/body weight) & $1.16(1.11$ to 1.22$)$ & $<0.0001$ \\
\hline Baseline creatinine $(\mu \mathrm{mol} / \mathrm{l})$ & $1.005(1.002$ to 1.007 & $<0.0001$ \\
\hline Urine output $<0.5 \mathrm{ml} / \mathrm{kg} / \mathrm{hour}$ (AKluo) & $2.50(1.60$ to 3.89$)$ & $<0.0001$ \\
\hline Urine output $<0.3 \mathrm{ml} / \mathrm{kg} /$ hour $\left(\mathrm{UO}_{<0.3}\right)$ & 5.21 (3.48 to 7.80$)$ & $<0.0001$ \\
\hline
\end{tabular}

$\mathrm{AKI}_{\mathrm{Cr}_{r}}$ acute kidney injury by the creatinine definition; $\mathrm{AK} \mathrm{UO}_{\mathrm{UO}}$, acute kidney injury by the urine output definition; MAP, mean arterial pressure; SAPS, Simplified Acute Physiological Score; $\mathrm{UO}_{<0.3}$, urine output $<0.3 \mathrm{ml} / \mathrm{kg} /$ hour averaged over 6 hours.

isolation. Other clinical predictors of AKI may need to be considered, including plasma creatinine changes, haemodynamic stability, vasopressor usage, and injury biomarkers [6]. To establish the biological plausibility of using low urine output as a marker of AKI, a study investigating the biological and temporal relationship of low urine output with other physiological endpoints including recovering verse nonrecovering plasma creatinine, peak plasma creatinine, urinalysis and kidney injury specific biomarkers is necessary.

\section{Study limitations}

This study has several limitations. First, the study was performed in only a single centre, so the generalisability of this study is significantly limited by the small sample size and the limited case mix. We note, however, a retrospective study by Mandelbaum and colleagues in more than 25,000 ICU patients that observed urine output $<0.3 \mathrm{ml} / \mathrm{kg} /$ hour for at least 5 hours was associated with increased mortality [29].

Second, this general ICU had a mean APACHE II score of $18 \pm 7$ (range 3 to 47 ). Forty per cent of patients $(n=287)$ had APACHE II score $>20$. While
APACHE II scores were taken into account in multivariate analysis, because other ICUs may include higher proportions of more severely ill patients, we recommend that a similar analysis be carried out in such a cohort to ensure that there is no bias introduced because of illness severity.

Third, of the 1,274 total ICU admissions screened, approximately one-third were admitted for $<24$ hours and these patients were excluded from the analysis. These patients included both those who did not survive 24 hours and those who were discharged within 24 hours. This exclusion may bias the results if a significant portion of those discharged early had low urine output.

Fourth, body weight was determined indirectly from the most recent body weight documented in medical records, or as reported by a patient or relative. In $6 \%$ (46 cases) these data were not available and body weight was estimated from the patient demispan. This estimate may affect the interpretation of the result if the body weight used was systematically either over or under the patient's true body weight. However, an analysis of urine output without factoring in body weight showed that a threshold of minimum 6-hourly urine output of $20 \mathrm{ml} /$ hour, which is the equivalent of $0.3 \mathrm{ml} / \mathrm{kg} /$ hour in an average 70-kg person, best associated with mortality.

Finally, diuretic administration may lead to misclassification of $\mathrm{AKI}_{\mathrm{UO}}$ or $\mathrm{UO}_{<0.3}$, and hence may mitigate the impact on these classifications in predicting outcome. A sensitivity analysis of patients without diuretic administration $(n=697)$ yielded similar odds ratios compared with the entire cohort (adjusted odds ratios for $\mathrm{UO}_{<0.3}$ of 3.89 (2.25 to 6.70) and $\mathrm{AKI}_{\mathrm{UO}}$ of 2.41 (1.35 to 4.31$)$ ).

\section{Conclusions}

The threshold for 6-hour urine output of an average of $0.3 \mathrm{ml} / \mathrm{kg} /$ hour was best associated with mortality or dialysis. This threshold was independently predictive of hospital mortality and 1-year mortality after adjustment for covariates. This suggests that the current AKI urine output definition may be too liberally defined. The optimal threshold of urine output was linearly related to duration. We recommend that a simple bedside formula

Table 6 Mortality or dialysis in $\mathrm{AKI}_{\mathrm{Cr}}$ and urine output at a threshold of $\mathbf{0}$

\begin{tabular}{|c|c|c|c|c|}
\hline \multirow[t]{2}{*}{ Urine output } & \multicolumn{2}{|c|}{ Mortality or dialysis, $n(\%)^{a}$} & \multicolumn{2}{|c|}{ Relative risk ${ }^{b}(95 \% \mathrm{Cl})$} \\
\hline & No-AKI $\mathrm{Cr}$ & $\mathrm{AKI}_{\mathrm{Cr}}$ & No-AKI $\mathrm{Cr}$ & $\mathrm{AKI}_{\mathrm{Cr}}$ \\
\hline$\geq 0.30 \mathrm{ml} / \mathrm{kg} /$ hour $\left(\mathrm{UO}_{\geq 0.3}\right)$ & 355 & 161 & & \\
\hline Mortality or dialysis & $27(7.6)$ & $24(14.9)$ & 1 (referent) & 1.96 (1.76 to 2.05$)$ \\
\hline$<0.30 \mathrm{ml} / \mathrm{kg} /$ hour $\left(\mathrm{UO}_{<0.3}\right)$ & 92 & 117 & & \\
\hline Mortality or dialysis & $23(25.0)$ & $53(45.2)$ & 3.29 (2.77 to 3.63$)$ & 5.96 (5.05 to 6.92) \\
\hline
\end{tabular}

$\mathrm{AKI}_{\mathrm{Cr}}$, acute kidney injury by the creatinine definition; $\mathrm{Cl}$, confidence interval; $\mathrm{UO}_{\geq 0.3}$, urine output $\geq 0.3 \mathrm{ml} / \mathrm{kg} /$ hour averaged over 6 hours; $\mathrm{UO}<0.3$, urine output $<0.3 \mathrm{ml} / \mathrm{kg} /$ hour averaged over 6 hours. ${ }^{\mathrm{a}}$ Number (percentage) of mortality or dialysis in each group. ${ }^{\mathrm{b}}$ Relative risk of mortality or dialysis to the referent group of No-AKI $\mathrm{Cr}_{\mathrm{r}}$ and $\mathrm{UO}_{\geq 0.3}$ 

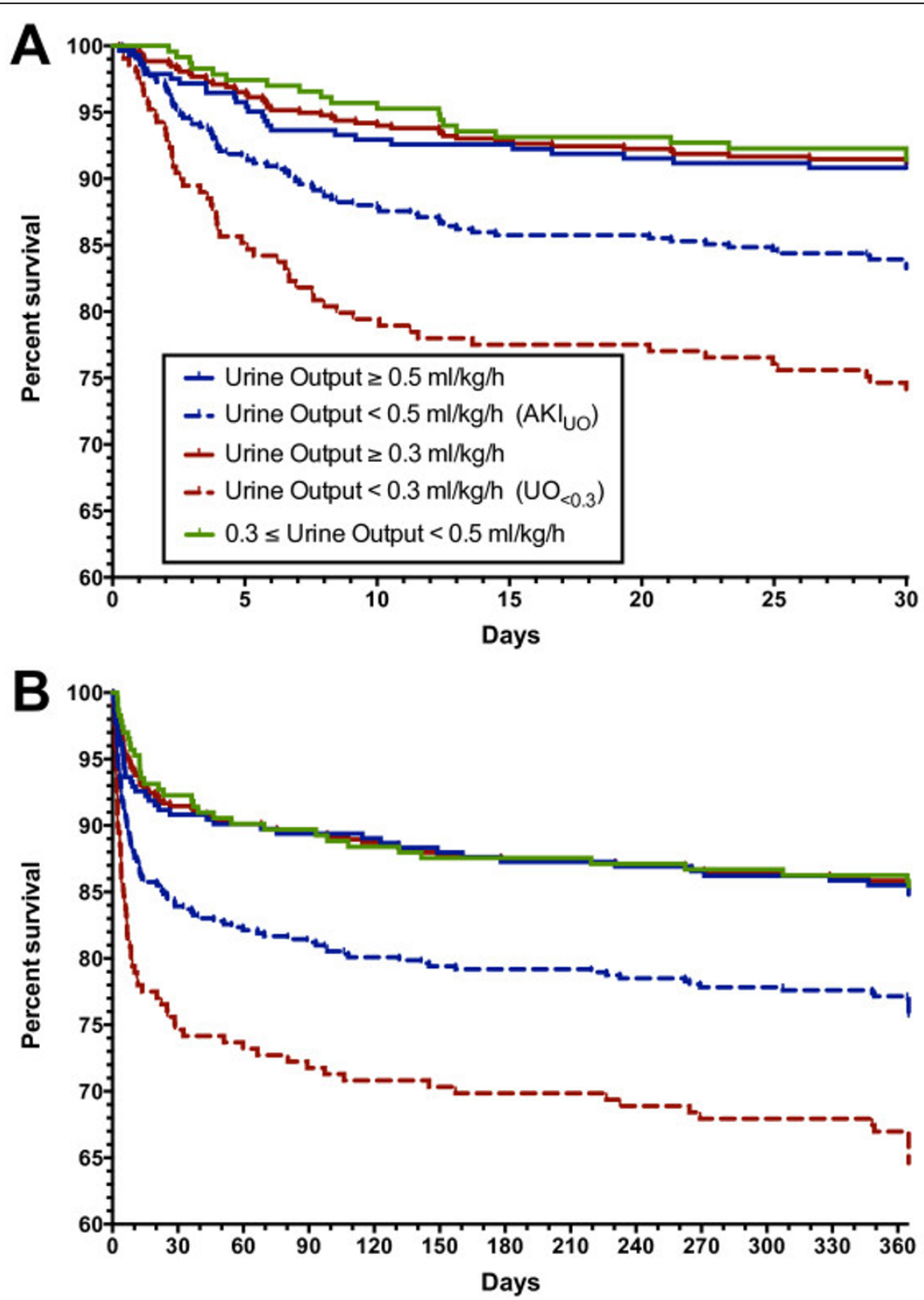

Figure 2 Kaplan-Meier survival curves. (A) In-hospital mortality. (B) One-year mortality. Log-rank test (Mantel-Cox): $P<0.0001$ for urine output $<0.3 \mathrm{ml} / \mathrm{kg} /$ hour $\left(\mathrm{UO}_{<0.3}\right)$ compared with urine output $\geq 0.3 \mathrm{ml} / \mathrm{kg} /$ hour in both cases (red lines), $P<0.01$ for urine output $<0.5 \mathrm{ml} / \mathrm{kg} / \mathrm{hour}$ (AKl $l_{\text {uo }}$ ) compared with urine output $\geq 0.5 \mathrm{ml} / \mathrm{kg} /$ hour in both cases (blue lines). There was no difference between urine output $>0.5 \mathrm{ml} / \mathrm{mg} / \mathrm{hour}$ (blue solid line) and 0.3 surine output $<0.5 \mathrm{ml} / \mathrm{kg} /$ hour (green line). (A) $P=0.77$, (B) $P=0.82$.

Table 7 Areas under the curve for varying durations of urine output from 1 to 6 hours

\begin{tabular}{|c|c|c|c|c|}
\hline Duration of urine output (hours) & AUC $(95 \% \mathrm{Cl})$ & $P$ value $^{a}$ & Optimal threshold (ml/kg/hour) & Relative risk $(95 \% \mathrm{Cl}$ \\
\hline 12 & 0.68 (0.63 to 0.73 ) & 0.054 & 0.47 & 2.69 (1.93 to 3.75$)$ \\
\hline 11 & 0.68 (0.64 to 0.73 ) & 0.095 & 0.48 & 2.53 (1.83 to 3.50$)$ \\
\hline 10 & 0.69 (0.64 to 0.73 ) & 0.087 & 0.37 & $2.52(1.83$ to 3.47$)$ \\
\hline 9 & 0.69 (0.64 to 0.74$)$ & 0.2 & 0.34 & 2.94 (2.14 to 4.06$)$ \\
\hline 8 & 0.70 (0.65 to 0.74$)$ & 0.64 & 0.33 & 3.27 (2.38 to 4.49$)$ \\
\hline 7 & 0.70 (0.65 to 0.74 ) & 0.76 & 0.31 & 3.39 (2.47 to 4.65$)$ \\
\hline 6 & 0.70 (0.65 to 0.74$)$ & 1 & 0.31 & 3.68 (2.68 to 5.04$)$ \\
\hline 5 & 0.69 (0.65 to 0.74$)$ & 0.23 & 0.30 & 3.45 (2.53 to 4.72$)$ \\
\hline 4 & 0.71 ( 0.66 to 0.75 ) & 0.47 & 0.23 & 3.61 (2.62 to 4.99$)$ \\
\hline
\end{tabular}


Table 7 Areas under the curve for varying durations of urine output from 1 to 6 hours (Continued)

\begin{tabular}{lllll}
\hline 3 & $0.69(0.64$ to 0.73$)$ & 0.17 & 0.23 & $3.03(2.22$ to 4.14$)$ \\
2 & $0.66(0.62$ to 0.71$)$ & 0.036 & 0.19 & $2.68(1.94$ to 3.68$)$ \\
1 & $0.61(0.56$ to 0.66$)$ & 0.0003 & 0.10 & $1.77(1.27$ to 2.48$)$ \\
\hline
\end{tabular}

Areas under the curve (AUCs) of varying durations of urine output from 1 to 6 hours for prediction of mortality or dialysis and relative risk for those below the threshold compared with those above the threshold. Comparisons were made in reference to the AUC of average hourly urine output over 6-hour period with the DeLong method. $\mathrm{Cl}$, confidence interval. ${ }^{\mathrm{a}} \mathrm{P}$ value for difference relative to 6 -hour urine output.

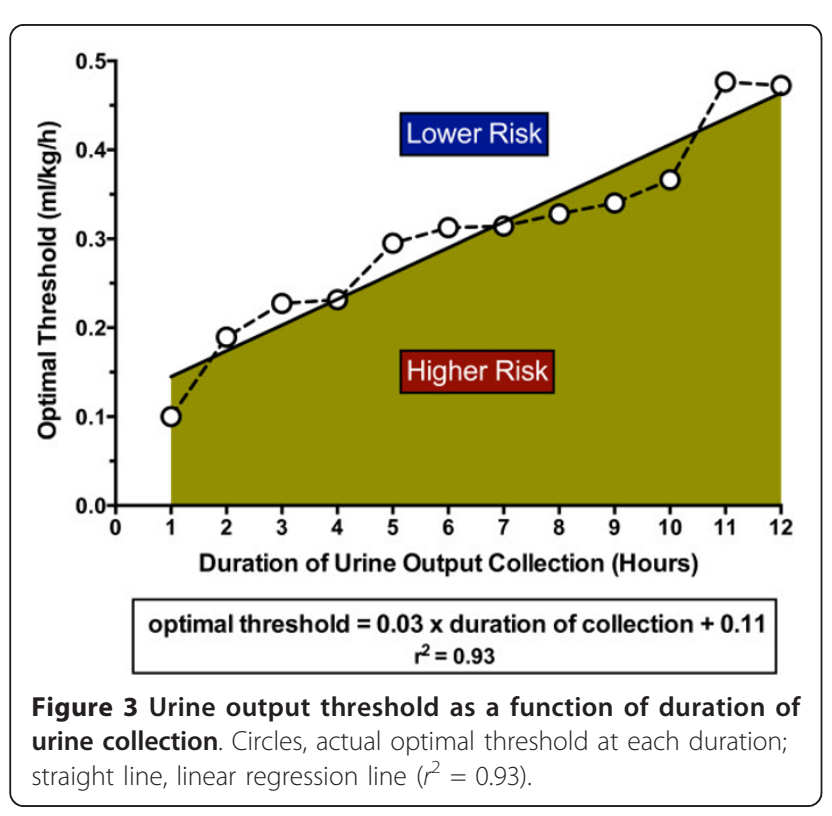

be applied to identify AKI; namely, for a duration of collection between 3 and 9 hours:

Urine output $(\mathrm{ml} / \mathrm{kg} /$ hour $)<0.03 \times$ duration of collection (hours) +0.11

\section{Key messages}

- A urine output threshold for defining AKI of $<0.5 \mathrm{ml} /$ $\mathrm{kg} /$ hour over 6 hours is too liberal.

- A threshold of $<0.3 \mathrm{ml} / \mathrm{kg} /$ hour over 6 hours better fits with the plasma creatinine definition of AKI by having a similar sensitivity for a clinically relevant outcome.

- AKI may be diagnosed from urine output in as little as 2 to 3 hours.

- The urine output threshold for AKI should be adjusted for duration of urine collection.

- AKI may be defined as: Urine output ( $\mathrm{ml} / \mathrm{kg} / \mathrm{hour}$ ) $<0.03 \times$ duration of collection (hours) +0.11 , where the duration is between 3 and 9 hours.

\section{Abbreviations}

AKI: acute kidney injury; $\mathrm{AKI}_{\mathrm{Cr}}$ : acute kidney injury by the creatinine definition; $\mathrm{AKI}_{\cup 0}$ : acute kidney injury by the urine output definition; APACHE: Acute Physiological and Chronic Health Evaluation; AUC: area under the curve; GFR: glomerular filtration rate; ROC: receiver operating characteristic; $\cup O_{\geq 0.3}$ : urine output $\geq 0.3 \mathrm{ml} / \mathrm{kg} /$ hour averaged over 6 hours; $\cup O_{<0.3}$ : urine output $<0.3 \mathrm{ml} / \mathrm{kg} /$ hour averaged over 6 hours.

\section{Competing interests}

The authors declare that they have no competing interests.

\section{Authors' contributions}

AMdR collected the data, performed the analysis, participated in data interpretation, wrote the first draft of the manuscript and approved the final manuscript. JWP oversaw the analysis, and participated in data interpretation, manuscript writing and approval. GMS assisted with data collection, participated in data interpretation and manuscript writing, and approved the manuscript. ZHE participated in data interpretation, manuscript writing and approval. All authors read and approved the final manuscript.

\section{Acknowledgements}

JWP was supported by a Marsden Foundation New Zealand government grant administered by the Royal Society of New Zealand, an infrastructure and enabling grant from the Australia New Zealand Society of Nephrologists, and a University of Otago Research Grant. AMdR was supported by the Malaysian Ministry of Higher Education and International Islamic University Malaysia. The authors thank the staff of Christchurch Hospital ICU for assistance in collecting data.

\section{Authors' details}

${ }^{1}$ Christchurch Kidney Research Group, Department of Medicine, University of Otago Christchurch, PO Box 4345, Christchurch 8140, New Zealand. ${ }^{2}$ Intensive Care Unit, Christchurch Hospital, Private Bag 4710, Christchurch 8011, New Zealand. ${ }^{3}$ Prince of Wales Hospital and Clinical School, University of New South Wales, High Street, Randwick, Sydney NSW 2031, Australia.

Received: 28 March 2013 Revised: 14 May 2013

Accepted: 20 June 2013 Published: 20 June 2013

\section{References}

1. Eknoyan G: Emergence of the concept of acute renal failure. Am J Nephrol 2002, 22:225-230.

2. Bellomo R, Ronco C, Kellum JA, Mehta RL, Palevsky PM, Acute Dialysis Quality Initiative Workgroup: Acute renal failure - definition, outcome measures, animal models, fluid therapy and information technology needs: the Second International Consensus Conference of the Acute Dialysis Quality Initiative (ADQI) Group. Crit Care 2004, 8:R204-R412.

3. Mehta RL, Kellum JA, Shah SV, Molitoris BA, Ronco C, Warnock DG, Levin A, Acute Kidney Injury Network: Acute Kidney Injury Network: report of an initiative to improve outcomes in acute kidney injury. Crit Care 2007, 11:R31.

4. KDIGO: Clinical practice guideline for acute kidney injury section 2: AKI definition. Kidney Int Suppl 2012, 2:19-36.

5. Joannidis M, Metnitz B, Bauer P, Schusterschitz N, Moreno R, Druml W, Metnitz PGH: Acute kidney injury in critically ill patients classified by AKIN versus RIFLE using the SAPS 3 database. Intens Care Med 2009, 35:1692-1702.

6. Prowle JR, Liu YL, Licari E, Bagshaw SM, Egi M, Haase M, Haase-Fielitz A, Kellum JA, Cruz DN, Ronco C, Tsutsui K, Uchino S, Bellomo R: Oliguria as predictive biomarker of acute kidney injury in critically ill patients. Crit Care 2011, 15:R172.

7. Ricci Z, Cruz DN, Ronco C: The RIFLE criteria and mortality in acute kidney injury: a systematic review. Kidney Int 2008, 73:538-546.

8. Wlodzimirow KA, Abu-Hanna A, Slabbekoorn M, Chamuleau RA, Schultz MJ, Bouman CS: A comparison of RIFLE with and without urine output criteria for acute kidney injury in critically ill patients. Crit Care 2012, 16:R200.

9. Macedo E, Malhotra R, Claure-Del Granado R, Fedullo P, Mehta RL: Defining urine output criterion for acute kidney injury in critically ill patients. Nephrol Dial Transpl 2011, 26:509-515. 
10. Macedo E, Malhotra R, Bouchard J, Wynn SK, Mehta RL: Oliguria is an early predictor of higher mortality in critically ill patients. Kidney Int 2011, 80:760-767.

11. Cruz DN, Bolgan I, Perazella MA, Bonello M, de Cal M, Corradi V, Polanco N, Ocampo C, Nalesso F, Piccinni P, Ronco C, North East Italian Prospective Hospital Renal Outcome Survey on Acute Kidney Injury NEiPHROS-AKI Investigators: North East Italian Prospective Hospital Renal Outcome Survey on Acute Kidney Injury (NEiPHROS-AKI): targeting the problem with the RIFLE Criteria. Clin J Am Soc Nephro 2007, 2:418-425.

12. Watson P, Watson I, Batt R: Total-body water volumes for adult males and females estimated from simple anthropometric measurements. Am J Clin Nutr 1980, 33:27-39.

13. Macedo E, Bouchard J, Soroko SH, Chertow GM, Himmelfarb J, Ikizler TA, Paganini EP, Mehta RL, Program to Improve Care in Acute Renal Disease Study: Fluid accumulation, recognition and staging of acute kidney injury in critically-ill patients. Crit Care 2010, 14:R82.

14. Knaus WA, Draper EA, Wagner DP, Zimmerman JE: APACHE II: a severity of disease classification system. Crit Care Med 1985, 13:818-829.

15. Le Gall JR, Lemeshow S, Saulnier F: A new simplified acute physiology score (SAPS II) based on a European/North American multicenter study. JAMA 1993, 270:2957-2963.

16. Pickering JW, Endre ZH: Linking injury to outcome in acute kidney injury: a matter of sensitivity. PLOS ONE 2013, 8:e62691.

17. Lassnigg A, Schmidlin D, Mouhieddine M, Bachmann L, Druml W, Bauer P, Hiesmayr M: Minimal changes of serum creatinine predict prognosis in patients after cardiothoracic surgery: a prospective cohort study. J Am Soc Nephrol 2004, 15:1597-1605.

18. Pickering JW, Endre ZH: GFR shot by RIFLE: errors in staging acute kidney injury. Lancet 2009, 373:1318-1319.

19. Bagshaw SM, Uchino S, Cruz DN, Bellomo R, Morimatsu H, Morgera S, Schetz M, Tan I, Bouman C, Macedo E, Gibney N, Tolwani A, Oudemans-van Straaten HM, Ronco C, Kellum JA, Beginning and Ending Supportive Therapy for the Kidney (BEST Kidney) Investigators: A comparison of observed versus estimated baseline creatinine for determination of RIFLE class in patients with acute kidney injury. Nephrol Dial Transpl 2009, 24:2739-2744.

20. Pickering JW, Endre ZH: Back-calculating baseline creatinine with MDRD misclassifies acute kidney injury in the intensive care unit. Clin J Am Soc Nephrol 2010, 5:1165-1173

21. Závada J, Hoste E, Cartin-Ceba R, Calzavacca P, Gajic O, Clermont G, Bellomo R, Kellum JA, AKI6 investigators: A comparison of three methods to estimate baseline creatinine for RIFLE classification. Nephrol Dial Transpl 2010, 25:3911-3918.

22. Pickering JW, Ralib AM, Endre ZH: Combining creatinine and volume kinetics identifies missed cases of acute kidney injury following cardiac arrest. Crit Care 2013, 17:R7.

23. Rabito CA, Panico F, Rubin R, Tolkoff-Rubin N, Teplick R: Noninvasive, realtime monitoring of renal function during critical care. J Am Soc Nephrol 1994, 4:1421-1428.

24. Pickering JW, Frampton CM, Walker RJ, Shaw GM, Endre ZH: Four hour creatinine clearance is better than plasma creatinine for monitoring renal function in critically ill patients. Crit Care 2012, 16:R107.

25. Cerda J: Oliguria: an earlier and accurate biomarker of acute kidney injury? Kidney Int 2011, 80:699-701.

26. Klahr S, Miller SB: Acute oliguria. N Engl J Med 1998, 338:671-675.

27. Teixeira C, Garzotto F, Piccinni P, Brienza N, lannuzzi M, Gramaticopolo S, Forfori F, Rocco M, Ronco C, Belluomo Anello C, Bove T, Carlini M, Michetti V, Pelaia P, Cruz DN, Nefroint NECISG: Fluid balance and urine volume are independent predictors of mortality in acute kidney injury. Crit Care 2013, 17:R14.

28. Rimmelé T, Kellum JA: Oliguria and fluid overload. Contrib Nephrol 2010, 164:39-45.

29. Mandelbaum T, Lee J, Scott DJ, Mark RG, Malhotra A, Howell MD, Talmor D: Empirical relationships among oliguria, creatinine, mortality, and renal replacement therapy in the critically ill. Intens Care Med 2013, 39:414-419.

30. Payen D, de Pont AC, Sakr Y, Spies C, Reinhart K, Vincent JL, Sepsis Occurrence in Acutely III Patients SOAP Investigators: A positive fluid balance is associated with a worse outcome in patients with acute renal failure. Crit Care 2008, 12:R74

31. Bouchard J, Soroko SB, Chertow GM, Himmelfarb J, Ikizler TA, Paganini EP, Mehta RL: Fluid accumulation, survival and recovery of kidney function in critically ill patients with acute kidney injury. Kidney Int 2009, 76:422-427.

32. Vaara ST, Korhonen A-M, Kaukonen K-M, Nisula S, Inkinen O, Hoppu S, Laurila JJ, Mildh L, Reinikainen M, Lund V, Parviainen I, Pettilä V, FINNAKI Study Group: Fluid overload is associated with an increased risk for 90day mortality in critically ill patients with renal replacement therapy: data from the prospective FINNAKI study. Crit Care 2012, 16:R197.

33. Ni Chonghaile M, Higgins B, Laffey JG: Permissive hypercapnia: role in protective lung ventilatory strategies. Curr Opin Crit Care 2005, 11:56-62.

\section{doi:10.1186/cc12784}

Cite this article as: Md Ralib et al: The urine output definition of acute kidney injury is too liberal. Critical Care 2013 17:R112.

\section{Submit your next manuscript to BioMed Central and take full advantage of:}

- Convenient online submission

- Thorough peer review

- No space constraints or color figure charges

- Immediate publication on acceptance

- Inclusion in PubMed, CAS, Scopus and Google Scholar

- Research which is freely available for redistribution

Submit your manuscript at www.biomedcentral.com/submit
Ciomed Central 